\title{
MODELING THE EFFECTS OF LAND USE AND CLIMATE CHANGE ON RIVERINE SMALLMOUTH BASS
}

\author{
James T. Peterson ${ }^{1}$ and Thomas J. KwaK ${ }^{2,3}$ \\ ${ }^{1}$ U.S. Forest Service, Rocky Mountain Research Station, 316 East Myrtle Street, Boise, Idaho 83702 USA \\ ${ }^{2}$ U.S. Geological Survey, Biological Resources Division, Arkansas Cooperative Fish and Wildlife Research Unit, \\ Department of Biological Sciences, University of Arkansas, Fayetteville, Arkansas 72701 USA
}

\begin{abstract}
Anthropogenic changes in temperature and stream flow, associated with watershed land use and climate change, are critical influences on the distribution and abundance of riverine fishes. To project the effects of changing land use and climate, we modeled a smallmouth bass (Micropterus dolomieu) population in a midwestern USA, large riverfloodplain ecosystem under historical (1915-1925), present (1977-1990), and future (2060, influenced by climate change) temperature and flow regimes. The age-structured model included parameters for temperature and river discharge during critical seasonal periods, fish population dynamics, and fishing harvest. Model relationships were developed from empirical field data collected over a $13-y r$ period. Sensitivity analyses indicated that discharge during the spawning/rearing period had a greater effect on adult density and fishing yield than did spawning/rearing temperature or winter discharge. Simulations for 100 years projected a $139 \%$ greater mean fish density under a historical flow regime $(64.9 \mathrm{fish} / \mathrm{ha})$ than that estimated for the present $(27.1 \mathrm{fish} / \mathrm{ha}$ ) with a sustainable fishing harvest under both flow regimes. Simulations under future climate-change-induced temperature and flow regimes with present land use projected a $69 \%$ decrease in mean fish density $(8.5 \mathrm{fish} / \mathrm{ha})$ from present and an unstable population that went extinct during $56 \%$ of the simulations. However, when simulated under a future climate-altered temperature and flow regime with historical land use, the population increased by $66 \%(45.0 \mathrm{fish} / \mathrm{ha})$ from present and sustained a harvest. Our findings suggest that land-use changes may be a greater detriment to riverine fishes than projected climate change and that the combined effects of both factors may lead to local species extinction. However, the negative effects of increased temperature and precipitation associated with future global warming could be mitigated by river channel, floodplain, and watershed restoration.
\end{abstract}

Key words: climate change; floodplain; flow regime; global warming; Kankakee River, USA; land use; Micropterus dolomieu; population model; simulation; smallmouth bass; streamflow; watershed restoration.

\section{INTRODUCTION}

Large river-floodplain ecosystems have been extensively altered by humans in North America, but are not well understood in terms of their ecological processes and the influence of anthropogenic activities (Welcomme 1985, Ward and Stanford 1989, Bayley 1995, Johnson et al. 1995). The flow regime, specifically the flood pulse, is considered the driving force in controlling ecosystem dynamics in river-floodplain systems and is influenced by large-scale processes, such as climate and land use (Junk et al. 1989, Johnson et al. 1995). Although large-scale processes in riverine systems are difficult to study empirically, knowledge of their influence is critical for developing effective management strategies.

Manuscript received 20 January 1998; revised 26 November 1998; accepted 14 December 1998; final version received 7 January 1999.

${ }^{3}$ Present address: U.S. Geological Survey, Biological Resources Division, North Carolina Cooperative Fish and Wildlife Research Unit, Box 7617, North Carolina State University, Raleigh, North Carolina 27695-7617 USA.
Lotic systems are influenced by atmospheric and terrestrial conditions over their watershed and will, presumably, be affected by climate change. Recent model projections suggest a global mean temperature rise of $1.0^{\circ}$ to $4.5^{\circ} \mathrm{C}$ and regional changes in precipitation of $-35 \%$ to $+50 \%$ associated with increases in atmospheric greenhouse gases (Houghton et al. 1996). Ecologists have expressed interest and concern for the potential effects that global climate change may exert on the environment and terrestrial and aquatic biota (e.g., Firth and Fisher 1992, Gates 1993, Kareiva et al. 1993, Vitousek 1994, Ringold and Groffman 1997). Regional variation in climate change further complicates the study and modeling of the corresponding changes in landscapes, habitats, and hydrology, and their effects on ecological processes and biota (Poff 1992, Rind et al. 1992).

Human activities that modify channel morphology and the watershed may dramatically alter the riverine flow regime and flood pulse. Channelization improves drainage or flood-carrying capacity, resulting in increases in channel slope, water velocity, and sediment 
transport (Gordon et al. 1992). Channelized basins show rapid runoff and lower water tables and usually experience accentuated flood peaks of shorter duration (Grover and Harrington 1966), whereas unaltered systems benefit from the ecological function and linkages of a prolonged, buffered flood-pulse (Junk et al. 1989). Furthermore, vegetation and shading are usually reduced in channelized reaches, which contributes to increases in water temperature and reductions in organic nutrient input (Gordon et al. 1992).

The stream and its catchment are integrated habitats, and thus, artificial alterations of the watershed result in changes to the stream channel, floodplain, flow regime, and biota. Any change occurring in the watershed necessitates a response that may occur elsewhere in the system (Morisawa 1985). Vegetation removal or change, road construction, and urbanization all affect drainage, runoff, infiltration, sedimentation, and hydrology of river systems (Grover and Harrington 1966, Morisawa 1985). Artificial drainage or clearing of land may produce an effect similar to that of stream channelization, where flood volumes and total runoff are increased with shorter flood duration (Grover and Harrington 1966, Gordon et al. 1992). These modifications to the physical environment, in turn, affect population and community dynamics of aquatic biota (e.g., Schlosser 1991, Lenat and Crawford 1994, Roth et al. 1996, Wiley et al. 1997).

Water temperature and flow regime are dominant physical factors influencing fish distribution and assemblage structure in lotic ecosystems (Matthews 1987, Wismer and Christie 1987, Fausch et al. 1988, Bain and Boltz 1989, Grossman et al. 1990). Although these two factors would be greatly influenced by climate change, little research has been conducted on projecting the effects of climate change on freshwater stream fishes and examining the interaction of climate with other environmental influences. Poff (1992) suggested several approaches to gain an understanding of environmental response to climate change. One approach is to develop models based on historical correlations during periods of natural climatic variation, which Guyette and Rabeni (1995) applied to growth rates of stream fishes in the Ozarks (USA). Another approach is to model projected responses under varying hypothetical climatic conditions, such as that of Keleher and Rahel (1996), who predicted losses of salmonid geographic range in Rocky Mountain (USA) streams associated with increased temperature.

To examine the response of a riverine fish population to changes in climate and land use, we adopted a modeling approach incorporating both historical, empirical correlations, and hypothetical projections under varying environmental conditions. First, we developed empirical relationships between the environmental conditions during critical, seasonal periods and the density, survival, and recruitment of smallmouth bass (Micropterus dolomieu) in a Midwestern USA, large river- floodplain ecosystem using data collected over a 13-yr period. These relationships were then integrated into an age-structured, smallmouth bass population model that included three basic elements: temperature and river discharge during critical seasonal periods, fish population dynamics, and fishing harvest. Model simulations under historical (1915-1925), present (19771990 , influenced by land use change), and future (2060, influenced by climate change) temperature and discharge regimes were conducted to predict long-term trends in fish abundance under differing scenarios of land use and climate. Our goal was to gain an understanding of the processes, direction, and trends in fish population responses to large-scale, environmental changes, rather than to precisely predict the future.

\section{Methods}

\section{The river basin and study reach}

The Kankakee River is a large lowland river that originates in northern Indiana and flows southwest for $241 \mathrm{~km}$ to its confluence with the Des Plaines River in Illinois where together they form the Illinois River (Fig. 1). The landscape of the Kankakee River basin has been altered dramatically during the past $150 \mathrm{yr}$. Prior to European settlement, the upper and middle portions of the watershed consisted of a series of extensive marsh prairies and forested swamp wetlands collectively known as the Grand Marsh (Meyer 1936). The Grand Marsh was once one of the largest marshswamp basins in the interior United States. Extensive draining and channelization of the Kankakee River basin for agriculture began in the mid-1800s, and the majority of channelization was completed by 1920 (Ivens et al. 1981). Following that period, drainage districts continued drainage activity in the form of levee construction, dredging outlet channels, and construction and maintenance of lateral ditches and tile mains (Barker et al. 1967, Ivens et al. 1981). By the 1960 s, $>40 \%$ of the Kankakee River basin land area had been artificially drained and converted into agriculture (Barker et al. 1967). These extensive land-use changes resulted in an average increase of 0.74 $\mathrm{m}^{3} \cdot \mathrm{s}^{-1} \cdot \mathrm{yr}^{-1}$ in the mean annual discharge of Kankakee River during 1916-1979 (Bhowmik et al. 1980). Although most of the upper and middle reaches of the river and tributaries have been channelized and are managed as an agricultural drainage project, downstream reaches remain relatively unaltered and meander naturally through complex mixtures of glacial tills, lacustrine sediments, and exposed bedrock, forming diverse aquatic habitats (Kwak 1993).

Fish surveys were conducted in a $2.5-\mathrm{km}$ reach of the Kankakee River in Will County, Illinois, USA (Fig. 1). At the study reach, $23.5 \mathrm{~km}$ upstream of its confluence with the Des Plaines River, the Kankakee River drains $12485 \mathrm{~km}^{2}$ (Healy 1979) and falls at a slope of $1.05 \mathrm{~m} / \mathrm{km}$ (Barker et al. 1967). Ten sampling stations, 


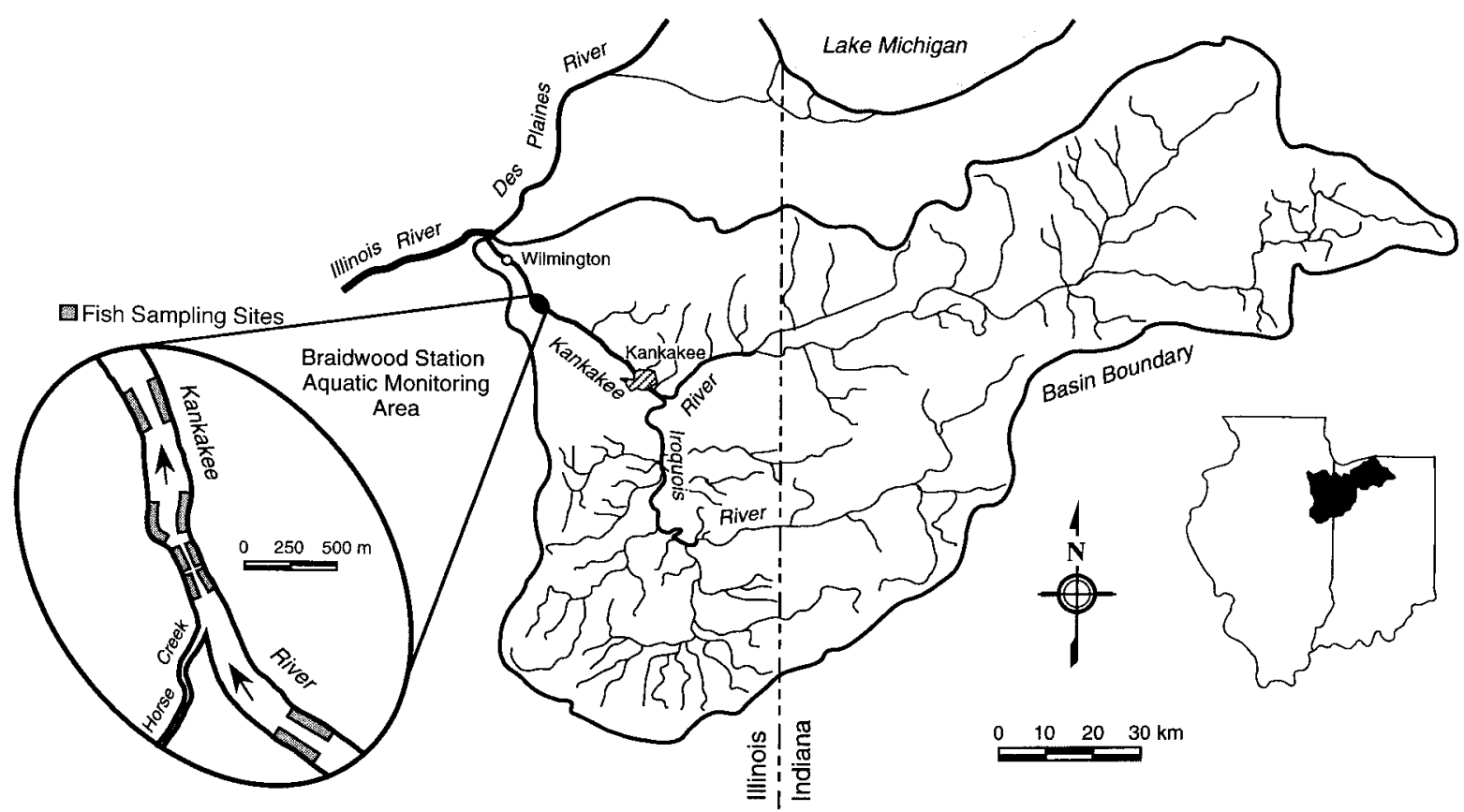

FIG. 1. Location of the Kankakee River, Illinois (USA), study reach, and stations sampled during annual fish surveys, 1977-1990.

established in the study reach, were representative of typical habitats in this system, i.e., riffles, gravel-cobble islands, shallow runs, moderately silted deep runs, and sand-silt backwaters. The physical habitat features of the reach remained relatively unaltered during the 13-yr study period (Peterson 1991). The mean daily discharge of the Kankakee River during the study period was $156 \mathrm{~m}^{3} / \mathrm{s}$ with a range of $8-1560 \mathrm{~m}^{3} / \mathrm{s}$ (USGS 1997).

\section{Fish sampling}

Fishes were sampled each year in August during 1977-1990 (excluding 1980). Streamflows are generally low during this month, and hence, age-0 smallmouth bass are susceptible to capture by electrofishing. Fishes were collected during daylight hours with a boat-mounted, 3-phase, AC electrofisher and standardized sampling procedure (Peterson 1991). Each station was sampled on four occasions within a 2 -wk period, with a minimum 2-d recovery period between collections to reduce the influence of previous sampling. All fish were measured for total length $( \pm 1 \mathrm{~mm})$ and weighed ( $\pm 1 \mathrm{~g}$ ). During 1985-1990, scales were removed from randomly selected individuals for subsequent age determination.

Selected physical habitat characteristics known to affect the efficiency of the boat electrofisher were measured at each station prior to fish sampling; i.e., water conductance, temperature, turbidity, current velocity, and mean depth (Bayley and Austen 1987). These characteristics differed among and within stations and over time, potentially biasing comparisons of fish density among cohorts and years (Bayley and Dowling 1993). To reduce the influence of sampling bias, length-frequency data were adjusted by applying gear-efficiency models for this specific gear prior to analyses (Austen 1992). Smallmouth bass density (no. fish/ha) for each year was estimated by summing the bias-adjusted catches for all stations and dates and dividing by the number of dates (4) and total area sampled (12.8 ha).

\section{Age determination}

Age classes of smallmouth bass collected during 1985-1990 were estimated by scale impression analysis (Smith 1954). Scale images were pressed onto acetate strips, which were projected on a screen. Annuli were identified according to criteria specified by Jearld (1983), and ages were assigned on the basis of the consensus of 3-5 readers. Age structure for the 19771984 fish collections was assessed using length-frequency analysis (Jearld 1983). Smallmouth bass were considered age 0 during their first year of life (corresponding to when fry are $<25 \mathrm{~mm}$ long), age classes 1 to 3 were considered juveniles, and adults (i.e., reproductively mature) were age 4 or greater (Smith 1979). Age-specific annual survival was estimated as the quotient of the density of any cohort and that cohort's density one year earlier.

\section{Environmental data}

Historical and recent daily discharge data for the Kankakee River were obtained from U.S. Geological Survey records for a gauging station located $5 \mathrm{~km}$ downstream of the study reach in Wilmington, Illinois, 


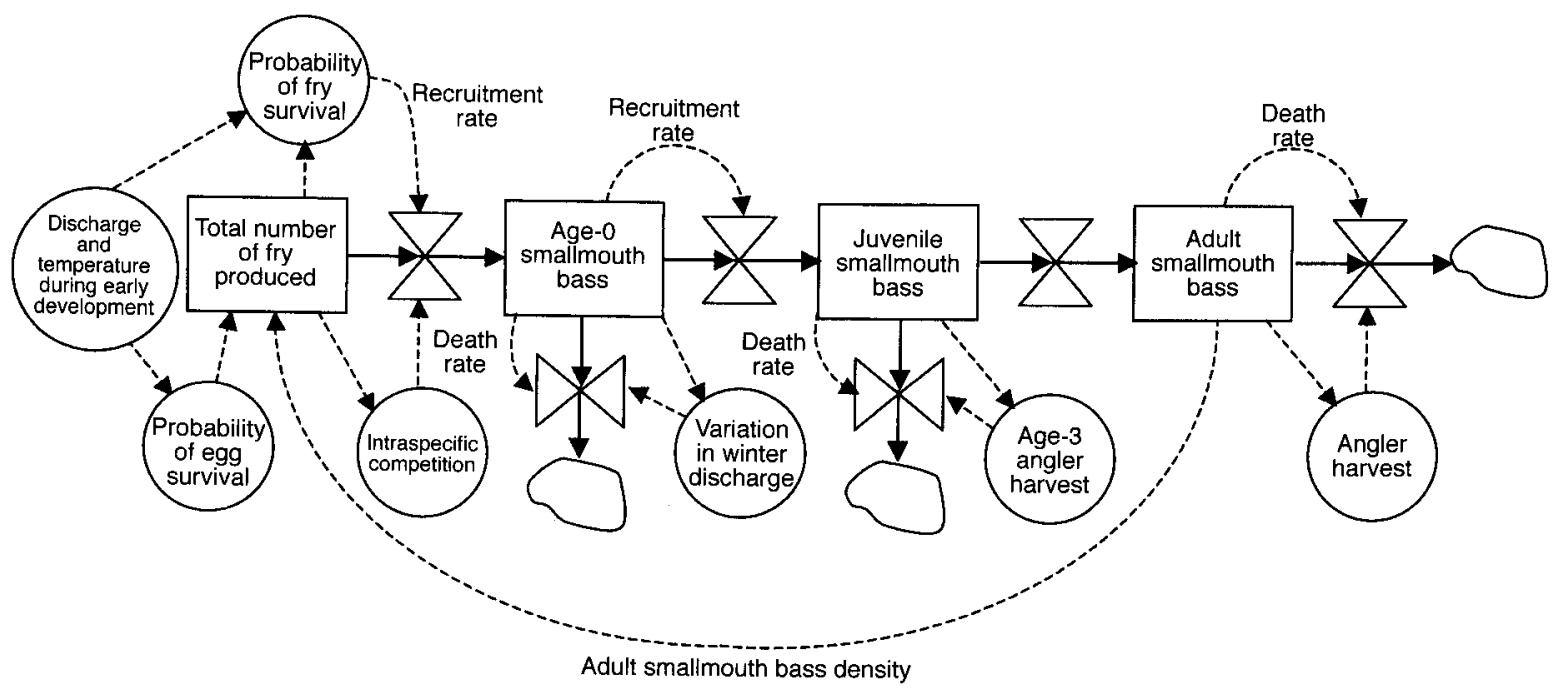

FIG. 2. Flow chart of basic structural relationships of the smallmouth bass population model using conventional symbols for rates (valves), levels (tubs), and variables (circles). Solid lines represent flow of material, and broken lines represent information links.

USA (USGS 1997). Daily water temperature data were not available for the Kankakee River after 1977. However, mean daily air temperature at the City of Kankakee, $\sim 30 \mathrm{~km}$ from the study reach, was significantly, positively correlated $\left(r^{2}=0.82 ; P<0.001\right)$ with mean daily water temperature in the Kankakee River for the period prior to 1977 (Kwak and Larimore 1987). Therefore, historical and recent daily air temperature data from a National Oceanic and Atmospheric Administration weather station $30 \mathrm{~km}$ from the study reach was incorporated into models in place of water temperature (National Oceanic and Atmospheric Administration, unpublished data for station 114593, Kankakee, Illinois, USA. National Climatic Data Center, Asheville, North Carolina USA).

Climate change projections for the Great Lakes Region associated with a doubling of $\mathrm{CO}_{2}$ or transient climate change to the year 2060 were obtained from Rind et al. (1989). These projections include seasonal temperature increases of $4.0^{\circ}-6.0^{\circ} \mathrm{C}$ and precipitation increases of $25.0 \%$ and $2.3 \%$ for summer and winter, respectively. Among numerous climate change scenarios derived from general circulation models (Houghton et al. 1990, 1996), we selected those of Rind et al. (1989) as conservative projections, which were similar in direction of change, but lower in magnitude, compared to those of other regional models (Giorgi et al. 1994).

Using the Rind et al. (1989) projections, we estimated climate-altered river discharges using the relationship:

$$
R_{2}=R_{1}\left(10^{1.77\left[\log _{10}\left(100 P_{2} / P_{1}\right)\right]+0.006 \Delta T-1.525}\right) / 100
$$

where $R_{1}$ and $R_{2}$ were discharge volumes (i.e., runoff) corresponding to $P_{1}$ (baseline) and $P_{2}$ (projected) precipitation rates and $\Delta T$ is the projected temperature change in ${ }^{\circ} \mathrm{C}$ (Karl and Riebsame 1989). Winter discharge standard deviation (SD), required for calculation of the coefficient of variation ( $\mathrm{CV}=\mathrm{SD} /$ mean [note that $\mathrm{CV}$ values reported in this paper are not percentages]) of winter discharge could not be estimated directly from Eq. 1 because of the presumably large, unknown covariance of $P_{1}$ and $R_{1}$. Consequently, winter discharge standard deviation was estimated for $R_{2}$ by assuming that $R_{1}$ and $P_{1}$ were constants.

\section{Model overview}

The smallmouth bass population model was based on our observations (Kwak and Larimore 1987, Peterson 1991) and those of other investigators (Pflieger 1966, Larimore and Duever 1968, Larimore 1975, Sallee et al. 1991, Bovee et al. 1994) that indicate that abiotic factors significantly influence lotic smallmouth bass reproductive success and survival during critical periods. Smallmouth bass reproductive success and survival are also known to be influenced by biotic factors (e.g., density dependence, competition, predation) and abiotic-biotic interactions (Eipper 1975, Emery 1975, DeAngelis et al. 1991, Harvey 1991). Thus, we estimated model parameters for factors that were previously reported to affect lotic smallmouth bass survival and reproduction with data collected during the 13-yr field study.

The Kankakee River smallmouth bass population model is an age-structured Leslie matrix formulation (Leslie 1945) composed of environmental factors (e.g., temperature and river discharge), fish population dynamics, and fishing harvest components (Fig. 2). The model operates on an annual time step from August to August, and is summarized in Table 1 . The model begins with a specified density for each of seven age classes, assuming that age -4 and older individuals are 
TABLE 1. Smallmouth bass population model parameters.

\begin{tabular}{|c|c|}
\hline Parameter & Estimate \\
\hline Age-0 density & $\begin{array}{l}\text { ADULT } \times \exp [6.9872-(\text { ADULT } \times \\
0.0437)-(Q \times 0.0342)+(0.0223 \times \\
\left.T)+E_{d}\right]\end{array}$ \\
\hline Age-0 survival & $0.63-(0.34 \times \mathrm{cv})+E_{s}$ \\
\hline Age-1 survival & constant; mean $=0.25, \mathrm{SD}=0.14$ \\
\hline Age-2 survival & constant; mean $=0.66, \mathrm{SD}=0.21$ \\
\hline Age-3 survival & $(1-\mathrm{HAR}) \times(1-\mathrm{NM})$ \\
\hline $\begin{array}{l}\text { Age-4 survival } \\
\text { Age-5 survival }\end{array}$ & $(1-$ HAR $) \times(1-\mathrm{NM})$ \\
\hline $\begin{array}{l}\text { Age-5 survival } \\
\text { Age-6 survival }\end{array}$ & $\begin{array}{l}(1-\mathrm{HAR}) \times(1-\mathrm{NM}) \\
0\end{array}$ \\
\hline$Q$ & $\begin{array}{l}\text { mean spawning/rearing (June-July) } \\
\text { discharge }\left(\mathrm{m}^{3 /} / \mathrm{s}\right)\end{array}$ \\
\hline ADULT & $\begin{array}{l}\text { total density of adult smallmouth bass } \\
\text { ages } 4 \text { and older (no. fish/ha) }\end{array}$ \\
\hline$E_{d}$ & $\begin{array}{l}\text { Age-0 density model error; mean }=0 \text {, } \\
\quad \mathrm{SD}=0.19\end{array}$ \\
\hline $\mathrm{CV}$ & $\begin{array}{l}\text { winter (December-February) discharge } \\
\text { coefficient of variation }\end{array}$ \\
\hline$E_{s}$ & $\begin{array}{l}\text { Age-0 survival model error; mean }=0 \text {, } \\
\text { SD }=0.023\end{array}$ \\
\hline HAR & $\begin{array}{l}\text { fishing harvest rate of smallmouth bass } \\
\text { ages } 3 \text { and older; mean }=0.42 \text {, } \\
\text { SD }=0.17\end{array}$ \\
\hline NM & $\begin{array}{l}\text { adult natural mortality; mean }=0.10 \text {, } \\
\qquad \mathrm{SD}=0.20\end{array}$ \\
\hline
\end{tabular}

Note: Fishing harvest rates are from Graham et al. (1984).

mature adults. Using average temperature and stream discharge during the spawning/rearing period (JuneJuly) and the density of adults from the previous year, age-0 fish density is predicted from a density-dependent, stock-recruitment relationship. These individuals are added to the population as age- 0 fish. Individuals in each age class are promoted to the next age class using annual survival rates. Age-0 survival (from age 0 to age 1) is estimated as a function of the stream discharge coefficient of variation during winter (December-February). Age-1 and age-2 survival rates are assumed constant, whereas survival of age- 3 and older individuals is a function of constant natural mortality and fishing mortality rates. Survival of age- 6 fish is assumed to be 0 . Stochasticity is imposed by randomly generating annual values for (1) temperature and flow during spawning/rearing, (2) coefficient of variation of flow during winter, (3) survival rates of age-1 and age-2 fish, and (4) natural mortality and harvest rates of age3 through age- 6 year classes. We impose additional stochasticity by randomly generating error terms for the stock-recruitment and age- 0 survival rate functions from normal distributions.

\section{Model parameters}

Reproduction.-To characterize the relationships between stream discharge/temperature and smallmouth bass reproductive success, we used the environmental-dependent Ricker stock-recruitment model (Fournier and Archibald 1982, Stocker et al. 1985). Prior to fitting the data with least squares regression (Neter et al. 1990), the Ricker model was linearized via natural log transformation as:

$$
\log \left(N_{i} / S_{i-1}\right)=\log (\alpha)-\beta S_{i-1}+\gamma_{1} Q_{i}+\gamma_{2} T_{i}+\varepsilon_{i}
$$

where $N_{i}$ is the density of age-0 fish in year $i, S_{i-1}$ is the adult density in year $i-1, Q_{i}$ is the mean daily discharge and $T_{i}$, the mean daily air temperature during the spawning/rearing period in year $i, \alpha$ and $\beta$ are stockrecruitment parameters, $\gamma_{1}$ and $\gamma_{2}$ are regression coefficients, and $\varepsilon_{i}$ is a normally distributed random variable with mean 0 and variance $\sigma^{2}$. The linear regression indicated that age-0 smallmouth bass density was significantly and negatively related to discharge during the spawning/rearing period $(P<0.001)$ and adult density $(P=0.012)$ during the previous year, whereas it was positively related to mean air temperature $(P=$ $0.0327)$. The overall model was statistically significant $(P<0.001)$ and explained $85.1 \%$ of the variation in age0 fish density. A plot of the observed and predicted values from the regression also suggested that the Ricker model fit reasonably well to the Kankakee River data (Fig. 3).
FIG. 3. Observed and predicted ratios of age- 0 to adult smallmouth bass densities from linear regression of reproductive success using the Ricker environmental stock-recruitment relationship. The dotted line represents perfect model fit.

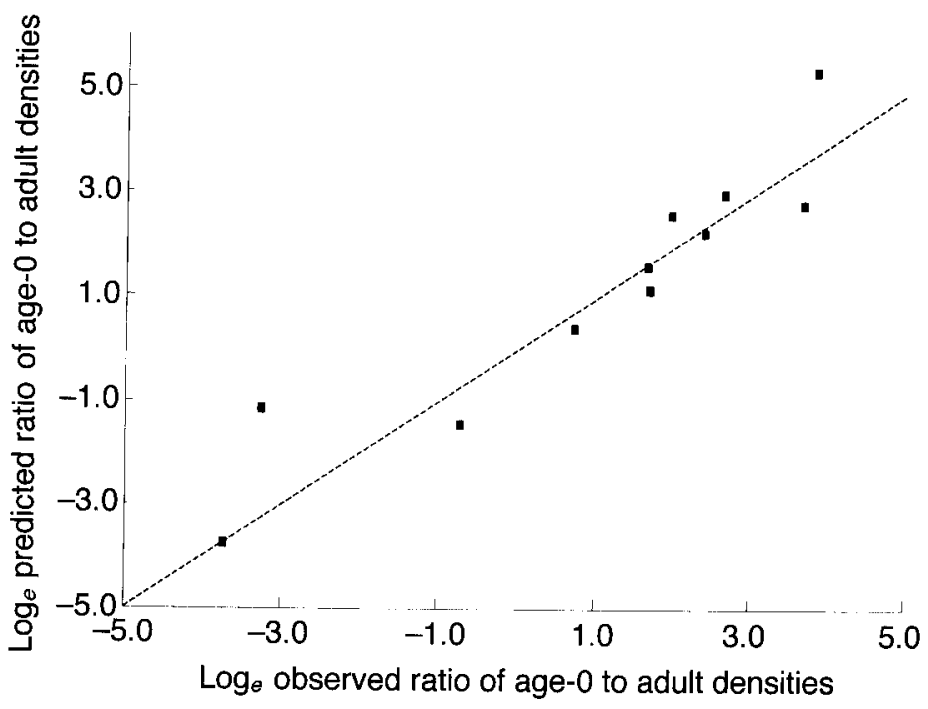


TABLE 2. Mean, range, and standard deviation (SD) of variables used for smallmouth bass population model parameter estimation.

\begin{tabular}{lccc}
\hline \hline \multicolumn{1}{c}{ Variable } & Mean & Range & SD \\
\hline Mean spawning/rearing discharge $\left(\mathrm{m}^{3} / \mathrm{s}\right) \dagger$ & 129.6 & $21-272$ & 61.5 \\
Mean spawning/rearing temperature $\left({ }^{\circ} \mathrm{C}\right)$ & 21.5 & $19-24$ & 1.8 \\
Winter discharge CV & 0.69 & $0.35-1.15$ & 0.28 \\
Age-1 smallmouth bass density (no. fish/ha) & 103.3 & $1-595$ & 162.2 \\
Age-2 smallmouth bass density (no. fish/ha) & 88.7 & $1-224$ & 96.0 \\
Age-3 smallmouth bass density (no. fish/ha) & 41.5 & $2-78$ & 2.3 \\
Age-4 smallmouth bass density (no. fish/ha) $\neq$ & 14.2 & 11.3 \\
Age-5 smallmouth bass density (no. fish/ha) $\ddagger$ & 6.5 & 1.6 & \\
Age-6 smallmouth bass density (no. fish/ha) $\neq$ & 3.8 & $0-7$ & 2.0 \\
\hline
\end{tabular}

Note: Coefficient of variation (Cv) is expressed as the standard deviation divided by the mean.

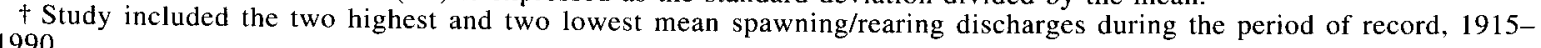
1990.

$\$$ Adult age class.

Age-O and juvenile survival.-The survival of age-0 smallmouth bass (to age 1) was modeled as a function of the coefficient of variation of streamflow during the winter period using least squares regression. The resulting linear model explained $85.1 \%$ of the variation in age- 0 survival and indicated that survival was significantly and negatively related to the coefficient of variation of discharge during the winter period $(P=$ $0.011)$. In contrast, an analysis of the survival rates of juvenile smallmouth bass (ages 1 to 3 ) in the Kankakee River indicated no statistically significant relationships $(P>0.05)$ with the factors considered in this study (Table 2). Therefore, we assumed that the survival of age-1 and age- 2 smallmouth bass was relatively constant and assigned each age class a mean survival and associated variance from that observed in our field study (Table 1). The survival of age- 3 fish, however, was modeled as a function of angling harvest.

Age-3 and adult survival.-S Sportfishing was a popular recreational activity on the Kankakee River during the field study, with smallmouth bass ages 3 and older comprising over $80 \%$ of the total harvest for this species (Graham et al. 1984). We modeled the survival of age- 3 and older fish as a function of fishing harvest rate, as estimated by Graham et al. (1984), and natural mortality (Table 1). Natural mortality of age- 3 and old- er fish was assumed to be relatively constant and was assigned mean and associated variance from that observed in our field study (Table 1). Age-6 survival was assumed to be zero, because no fish exceeding that age were collected during our field study.

\section{Equilibrium sensitivity analysis}

Prior to conducting simulation experiments, we analytically examined some of the smallmouth bass population model characteristics. The model's population equilibrium size, under varying flow and temperature regimes, was estimated by setting the number of recruits (i.e., young surviving to adulthood) per adult equal to the number of adults per recruit and solving for the number of adults (Ricker 1954). This is graphically depicted in Fig. 4 as the intersection of the stockrecruitment curves (i.e., the number of recruits per adult) with the straight line representing the number of adults per recruit. The relative influence of each discharge component and temperature (sensitivity) then was examined by estimating the adult equilibrium density for various combinations of mean spawning/rearing discharge, mean spawning/rearing air temperature, and winter discharge coefficient of variation.

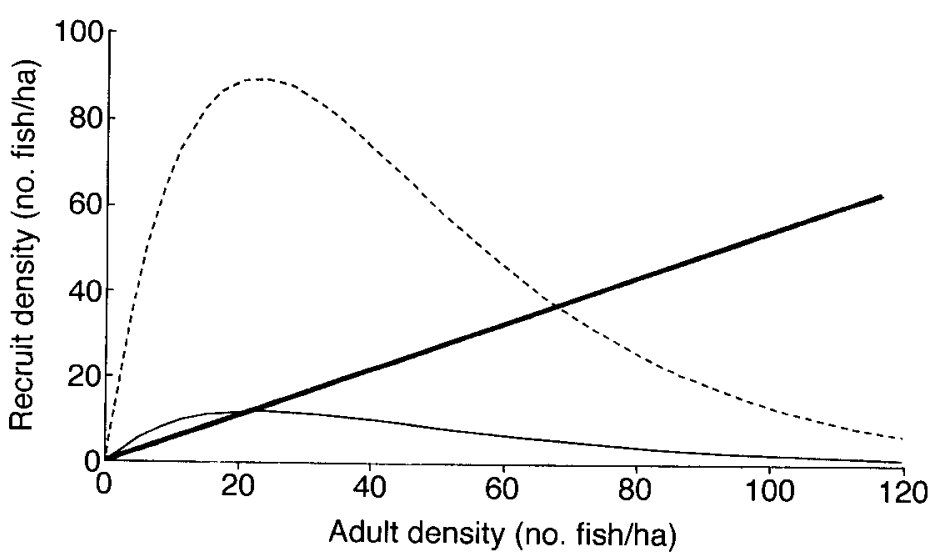

FIG. 4. Number of recruits per adult estimated for smallmouth bass in the Kankakee River under current (thin solid line) and historical (broken line) flow regimes. Adult equilibrium densities are the points where the number of adults per recruit (thick solid line) intersects each stock-recruitment curve. 
TABLE 3. Historical, present, and projected temperature and flow regimes and simulated smallmouth bass densities for the Kankakee River, Illinois (USA).

\begin{tabular}{|c|c|c|c|c|}
\hline \multirow[b]{2}{*}{ Time period } & \multicolumn{2}{|c|}{ Mean spawning/rearing } & \multirow{2}{*}{$\begin{array}{c}\text { Mean winter } \\
\text { discharge CV }(\%)\end{array}$} & \multirow{2}{*}{$\begin{array}{c}\text { Mean adult } \\
\text { smallmouth bass } \\
\text { density } \\
\text { (no. fish/ha) }\end{array}$} \\
\hline & Discharge $\left(\mathrm{m}^{3} / \mathrm{s}\right)$ & Temperature $\left({ }^{\circ} \mathrm{C}\right)$ & & \\
\hline \multicolumn{5}{|l|}{ Historical } \\
\hline 1915-1925 & 72.2 & $21.6 \dagger$ & 0.58 & 64.9 \\
\hline \multicolumn{5}{|l|}{ Present } \\
\hline $1977-1990$ & 129.6 & 21.5 & 0.69 & 27.1 \\
\hline \multicolumn{5}{|l|}{ Future projections } \\
\hline $\begin{array}{l}\text { Under historical land use } \\
\text { Under present land use }\end{array}$ & $\begin{array}{l}116.8 \\
209.7\end{array}$ & $\begin{array}{l}25.5 \\
25.5\end{array}$ & $\begin{array}{l}0.39 \\
0.45\end{array}$ & $\begin{array}{l}45.0 \\
8.5 \ddagger\end{array}$ \\
\hline
\end{tabular}

Notes: Future projections were derived using relative precipitation estimates from Rind et al. (1989) associated with a doubling of $\mathrm{CO}_{2}$ or transient climate change to the year 2060 , which corresponded to seasonal temperature increases of $4.0^{\circ}-$ $6.0^{\circ} \mathrm{C}$ in the Great Lakes Region (USA), and a precipitation-temperature-discharge relation for North American streams (Karl and Riebsame 1989). Coefficient of variation (CV) is expressed as the standard deviation divided by the mean.

$\uparrow$ Temperature records began in 1917 .

$\doteqdot$ Population went extinct in $56 \%$ of simulations (mean, $61 \mathrm{yr}$; range, 18-100 yr).

\section{Simulation experiments}

Two sets of simulations were executed to examine the influence of streamflow and temperature conditions, influenced by land use and climate change, on longterm smallmouth bass population trends and fishing yield-harvest rate relationships. In the first set of simulations, we examined the long-term adult population density under four discharge and temperature regimes. The second set of simulations imposed increasing harvest rates under each of the four discharge and temperature regimes from the first set of simulations. Our model parameters and algorithms were developed using empirical relationships, but such simulations should not be viewed as empirical estimates of future population size. Population models are, at best, crude representations of natural processes and cannot account for all factors and complex interactions that may affect a population. However, an examination of population trends, over multiple iterations, will provide an indication of the relative influence of temperature and flow regime on smallmouth bass population size in this system.

Each simulation included 1000 replicates of $100-\mathrm{yr}$ duration with adult density output during each annual time-step. For each replicate simulation, the initial density of each age class was randomly set from a range of 0-300 fish/ha, and non-manipulated components (e.g., age- 1 and age-2 survival rates) were set at $1977-$ 1990 averages (Tables 1 and 2). Year-to-year variability was imposed on spawning/rearing discharge and temperature, winter discharge coefficient of variation, fishing harvest rate, and survival rates of age- 1 and older fish during all simulations. These components varied normally among years with a standard deviation proportional to the mean. That proportion was determined from the means and standard deviations of field study values (Tables 1 and 2). For example, the among-year variation (SD) of mean discharge during spawning/rear- ing was $61.5 \mathrm{~m}^{3} / \mathrm{s}$, which is $0.47(47 \%)$ of the grand mean, $129.6 \mathrm{~m}^{3} / \mathrm{s}$ (Table 2). Thus, the mean discharge for each annual time-step was randomly selected from a normal distribution with a standard deviation 0.47 times the mean. When unlikely component values were randomly selected (e.g., negative discharge or survival rate), new values were chosen from the same distribution. This process resulted in nearly the full range of values observed during the field study being included in simulations.

The potential effect of land use and climate change on long-term smallmouth bass population trends was examined by executing simulations using the mean spawning/rearing discharge and air temperature and the winter discharge coefficient of variation values from: (1) the earliest dates with available data (1915-1925; Table 3), which we define as "historical" values, imposing no effect; (2) our field study (1977-1990), which we define as "present" values, imposing an altered land-use effect; (3) climate change projections under historical land use, which we define as "projected under historical," imposing a climate-change effect; and (4) climate change projections under present land use, which we define as "projected under present," imposing climate-change and altered land-use effects.

In the fishing yield-harvest rate simulations, we initially set the harvest rate at $10 \%$ and ran a 1000 -replicate simulation, which output the mean annual yield. This process was repeated with the harvest rate increasing in $10 \%$ increments until the harvest rate reached $100 \%$. The maximum annual yield was estimated by examining the mean annual yield-harvest rate relationship derived from distance-weighted least squares fit (Wilkinson et al. 1992).

\section{Results}

Analytical evaluation of the population model indicated that mean spawning/rearing discharge had a 

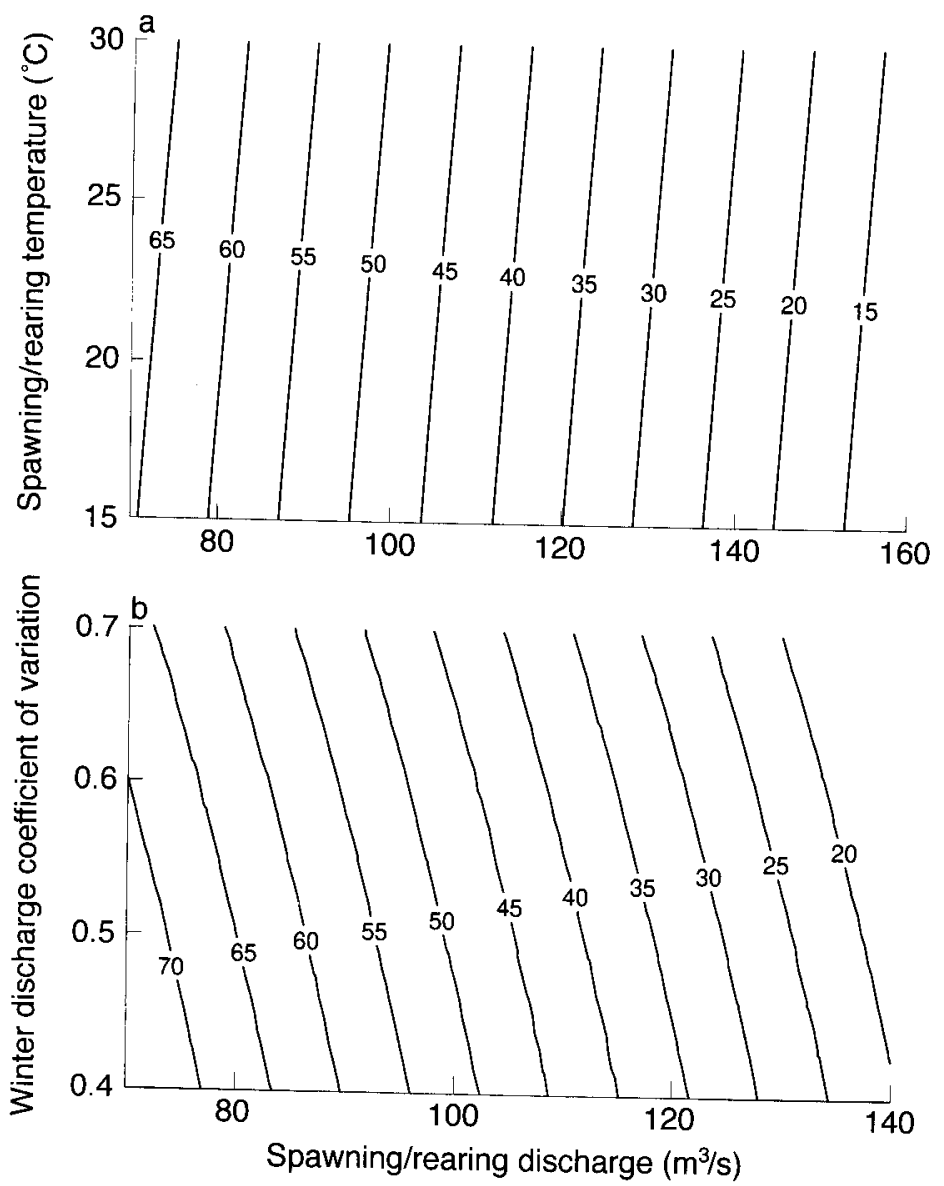

FIG. 5. Response surface of predicted smallmouth bass population equilibria for various combinations of mean discharge during spawning/rearing and (a) mean air temperature during spawning/rearing with a 0.55 winter discharge coefficient of variation, and (b) winter discharge coefficient of variation with a $20^{\circ} \mathrm{C}$ mean spawning/rearing air temperature. Lines represent adult equilibrium density (no. fish/ha) for specific discharge and temperature combinations. much greater effect on adult smallmouth bass density than either mean spawning/rearing air temperature or winter discharge coefficient of variation (Fig. 5). For example, under a mean spawning/rearing discharge of $100 \mathrm{~m}^{3} / \mathrm{s}$, mean spawning/rearing temperature of $20^{\circ} \mathrm{C}$, and winter discharge $\mathrm{CV}$ of 0.55 , the model predicted an equilibrium density of 47.8 fish/ha (Fig. 5). A $25 \%$ increase or reduction in the mean spawning/rearing discharge corresponded to a $42.2 \%$ decrease (27.6 fish/ ha) or $40.8 \%$ increase (67.3 fish/ha) in mean density, respectively. In contrast, a $25 \%$ increase or reduction of spawning/rearing temperature corresponded to less extreme changes in mean adult density of $6.0 \%$ increase $(50.7 \mathrm{fish} / \mathrm{ha})$ and $5.9 \%$ decrease $(45.0 \mathrm{fish} / \mathrm{ha})$, respectively (Fig. 5a). Similarly, a $25 \%$ increase or reduction of winter discharge coefficient of variation simulated a $9.2 \%$ decrease $(43.4 \mathrm{fish} / \mathrm{ha}$ ) and $7.1 \%$ increase (51.2 fish/ha), respectively (Fig. 5b).

Simulations incorporating the historical temperature and flow regimes predicted substantially greater adult smallmouth bass density, annual fishing yield, and maximum sustainable harvest rate, compared to similar estimates under the corresponding present regimes (Table 3, Fig. 6), suggesting that altered land use resulted in reduced fish populations. Under historical temper- ature and flow regimes, estimated densities averaged 64.9 fish $/$ ha, $140 \%$ greater than the estimated mean density (27.1 fish/ha) under present conditions (Fig. 6a). Similarly, estimated annual fishing yield for all harvest rates was $80 \%$ lower, and estimated maximum sustainable harvest rate (i.e., the rate at which annual yield is maximized; Fig. 6b) was $38 \%$ lower under present temperature and flow regimes than those simulated under historical conditions (Fig. 6b).

Based on estimates of relative temperature and precipitation change for the Great Lakes Region (Rind et al. 1989), our projections from the historical and present Kankakee River flow regimes suggested a relative increase for mean spawning/rearing discharge and a decrease for winter discharge coefficient of variation (Table 3). Simulations under future climate-change induced temperature and flow regimes with present land use projected a $69 \%$ decrease in mean smallmouth bass density ( $8.5 \mathrm{fish} / \mathrm{ha}$ ) from that of the present, and in $56.0 \%$ of these simulations, the population was very unstable and went extinct (Table 3, Fig. 6a). However, when simulated under future climate-altered temperature and flow regimes with historical land use, the population increased by $66 \%$ ( $45.0 \mathrm{fish} / \mathrm{ha})$ from that of the present. Furthermore, the simulated effects of land- 
Conditions (imposed effect)

- Historical (none)

---- Projected climate, historical land use (climate change)

- Present (altered land use)

- - Projected climate, present land use (climate change and altered land use)
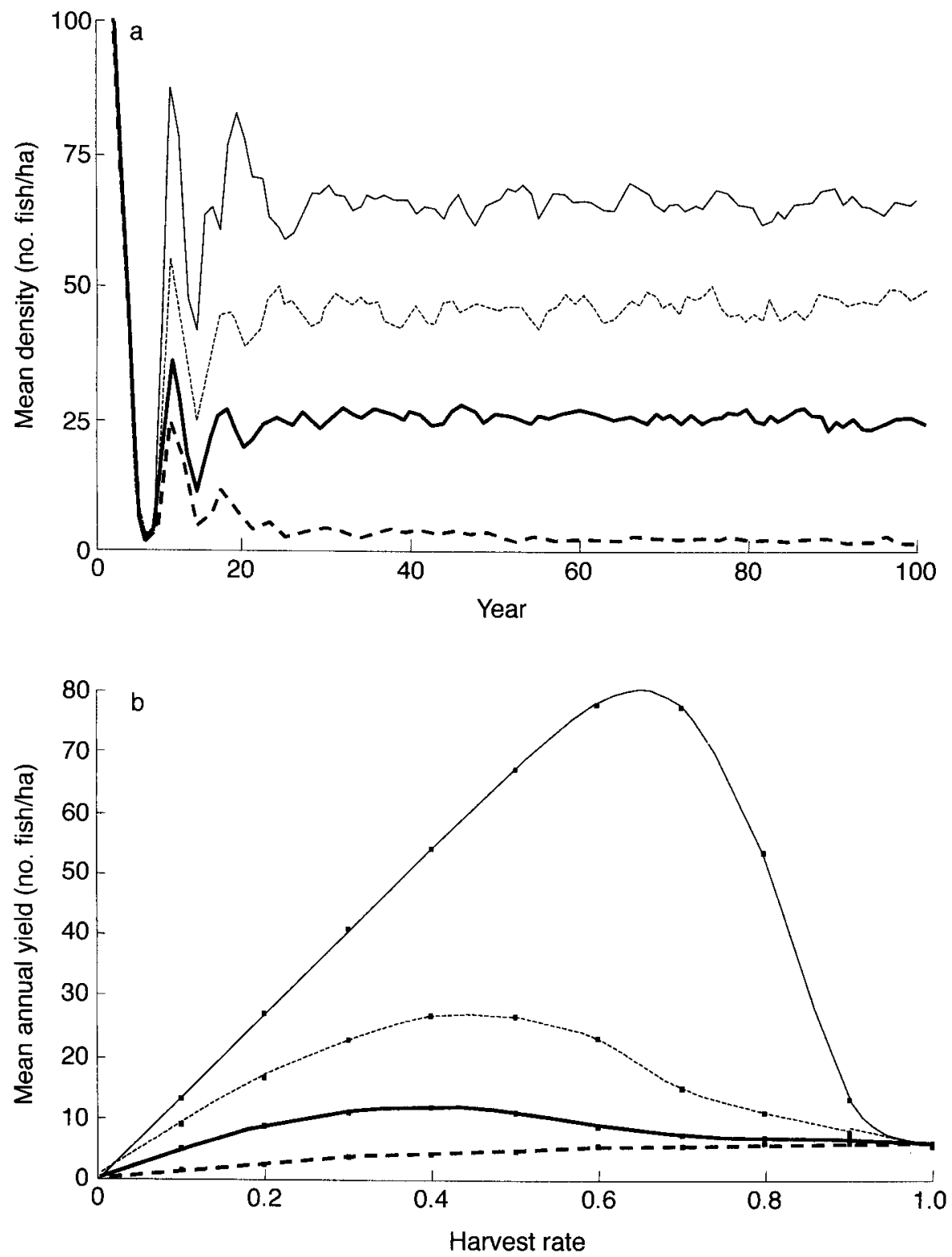

FIG. 6. Predicted (a) adult (age-4 and older) population density and (b) relationships between annual fishing yield and harvest rates for smallmouth bass using historical and present flow regimes and projections based on climate-induced precipitation and temperature changes (Rind et al. 1989). Lines each represent a mean population trend of 1000 replicate simulations. Annual fishing yield is the mean of $100-\mathrm{yr}$ simulations with harvest rate expressed as the proportion of age- 3 and older fish removed per year.

use changes over 75 years $(58 \%$ decrease in fish density) were more detrimental to the smallmouth bass population than those of an equivalent period of climate change ( $31 \%$ decrease in fish density). Similar patterns were observed for fishing yield-harvest rate relation- ships with $79 \%$ and $61 \%$ lower mean annual fishing yield, across harvest rates, for temperature and discharge projections from present and historical conditions, respectively (Fig. 6b). Estimated maximum sustainable harvest rates could not be determined for sim- 
ulations of projections from present conditions, because the population went extinct during simulations of climate change projections at all harvest rates.

\section{DISCUSSION}

\section{Ecological implications}

Flow regime strongly influenced the production and overwinter survival of age-0 smallmouth bass in the Kankakee River during 1977-1990, which was consistent with other research and observations (Cleary 1956 , Pflieger 1966, Larimore and Duever 1968, Larimore 1975, Sallee at al. 1991, Bovee et al. 1994). Stream discharge fluctuations have been found to negatively impact age- 0 smallmouth bass through direct mortality associated with longitudinal displacement of eggs and fry (Pflieger 1966, Larimore 1975, Winemiller and Taylor 1982, Simonson and Swenson 1990, Lukas and Orth 1995) and indirectly, by increasing turbidity which can inhibit feeding, reduce prey availability, and disturb fry orientation (Larimore 1975). Furthermore, young fish may be more vulnerable to the detrimental effects of flow fluctuations during winter and periods of decreased temperature (Larimore and Duever 1968, Horning and Pearson 1973, Coble 1975).

Our simulations suggested that mean discharge of the Kankakee River during the spawning/rearing period was a much greater influence on the subsequent density of adult smallmouth bass than temperature during spawning/rearing or discharge fluctuations during winter. For example, a $25 \%$ increase or reduction in mean spawning/rearing discharge had at least a 596\% greater impact on adult density than did a similar change in spawning rearing temperature and at least a $419 \%$ greater effect than that of winter discharge coefficient of variation (Fig. 5). We believe that our results were not an artifact of model structure or an atypical response found in the Kankakee River population. In an extensive review of smallmouth bass research, Coble (1975) reported that cohort density could fluctuate as much as $500 \%$ among years, with fluctuations likely related to weather conditions during the first summer of life. The dominant effect of river discharge during spawning/rearing on reproductive success and density that we modeled is also similar to that simulated for water level on reservoir smallmouth bass populations (Clark et al. 1998). However, bioenergetic modeling suggests that temperature is a more important influence on smallmouth bass reproductive success and survival in lakes and especially at the margins of the species' distribution (Shuter et al. 1980, 1989).

Previous studies of the potential effects of climate change on freshwater fish distribution and survival have focused on the influence of temperature change. Indeed, the direct effects of elevated temperature may be critical to the survival and distribution of coldwater fishes (Meisner 1990, Eaton and Scheller 1996, Keleher and Rahel 1996, Rahel et al. 1996) and for smallmouth bass near the margins of their distribution (Shuter et al. 1980, 1989, Shuter and Post 1990). Our results, however, suggest that changes in flow regime associated with altered precipitation patterns are much more influential than temperature effects to a riverine smallmouth bass population in the center of the species' range. We urge that seasonal changes in precipitation be considered, in addition to those of temperature, in future studies to project the effect of climate change on lotic fish populations.

There are several assumptions and limitations inherent in our modeling approach. For example, although we incorporated intraspecific density dependence via stock-recruitment functions, our model did not explicitly include interspecific density dependence or resource competition. We assumed that the ecological relationships (e.g., environmental influences, density dependence, predator-prey dynamics) observed during a recent, 13-yr period apply to past and future periods of altered land use and climate conditions. However, this assumption may be reasonable, because the extremes in environmental conditions for the period of record (1915-1990; spawning/rearing discharges; Table 2) occurred during our field study, and the environmental conditions simulated were well within the range of values under which the model was parameterized. Further, the age-based structure of our model implies that all individuals in an age class are identical. Although this level of stratification or reduction (i.e., cohort) is intermediate, relative to modeling individuals or population averages (Lomnicki 1992), we contend that there is little loss of information at the cohort level, and that the approach is reasonable for examining the response of a fish population to large-scale, longterm, environmental changes.

\section{Instream and watershed management implications}

A major question to consider in management to sustain or enhance lotic fish populations is: What is the primary limiting factor to the population or assemblage of interest? Our field research and simulations highlight the importance of flow regime to smallmouth bass populations, especially detrimentally high flows during spawning and early life stages. Thus, high flows and discharge variability should be considered in addition to minimum streamflow regulations, which are implemented to protect stream habitats during low-flow periods (Bovee and Milhous 1978, Stalnaker 1981, Morhardt 1986), for protecting smallmouth bass populations. Conversely, many other Kankakee River fish species, including the rare and protected pallid shiner (Notropis amnis), appear to benefit from high spring and summer flows that allow access and utilization of lateral floodplain habitats (Kwak 1988, 1991). In fact, many riverine fishes are adapted to, and may be dependent upon, access to the floodplain for their survival (Ross and Baker 1983, Kwak 1988), and fish production is strongly related to the amount of accessible 
floodplain (Junk et al. 1989). Furthermore, most fishes that occur primarily in the river channel, such as smallmouth bass, depend on primary and forage production from the laterally-linked floodplain when it is present and regularly inundated (Junk et al. 1989). These varied and seemingly conflicting habitat requirements among fishes create a challenge to be considered by resource managers attempting to manage at the ecosystem level with maintaining or enhancing fish production, biodiversity, and ecological integrity as goals.

A stream's flow regime is, in part, influenced by its watershed landscape characteristics, such as valley slope, geomorphic history, and land-use patterns (Leopold et al. 1964, Morisawa 1985). Of these, land use is the characteristic most frequently and extensively altered by humans (Schlosser 1991, and references cited therein). Near the turn of the century, Forbes and Richardson (1920) noted for the Kankakee River that "water flows off much sooner after it falls, and consequently the river is higher during the autumn and spring floods and lower at other seasons than formerly". That early observed trend has continued and become more extreme over time, as the mean annual flow in the Kankakee River has increased $0.74 \mathrm{~m}^{3} / \mathrm{s}$ annually from 1916-1979 and $1.08 \mathrm{~m}^{3} / \mathrm{s}$ annually from $1931-$ 1979 without a corresponding trend in precipitation (Bhowmik et al. 1980). This rate of increase was similarly reflected in the $1.10-\mathrm{m}^{3} / \mathrm{s}$ annual increase that we found for mean spawning/rearing discharge from 1925-1977 (Table 3). These observations and empirical data for the Kankakee River support the general conclusion of hydrologists that land drainage and urbanization may increase flood discharges with sharper peaks and shorter duration and increase total runoff by decreasing evaporative losses associated with reduced wetted surface areas (Grover and Harrington 1966).

Our simulations suggest that land-use changes also had a presumably unintended negative effect on the Kankakee River smallmouth bass population. Assuming that the present physical habitat features of the relatively unaltered, downstream reaches of the Kankakee River are similar to those during 1915-1925, our post hoc estimates suggest that adult smallmouth bass densities during the past may have been as high as 64.9 fish/ha, $\sim 139 \%$ greater than the average 1977-1990 density. Although our estimates of historical fish density may appear relatively high, they range well below published density estimates of other productive streamdwelling smallmouth bass populations (e.g., 84-146 fish/ha, Roell and Orth [1993]; 41-278 fish/ha, Rabeni [1992]; 650-681 fish/ha, Waters et al. [1993]). Furthermore, the decrease in Kankakee River smallmouth bass abundance over time that we estimated is in accord with a restriction in distribution and general decline of the species in Illinois, described by Smith (1979), which he attributed to siltation, deteriorated water quality, and fluctuating flows.

Flow regime is also influenced by climatic factors, such as air temperature and the frequency, amounts, and types of precipitation (Leopold et al. 1964). Regional projections of future climate patterns predict season-specific increases in temperature and precipitation for the Great Lakes Region (Rind et al. 1989, Giorgi et al. 1994). Of these two factors, several studies have shown that stream discharge is most sensitive to changes in precipitation (Wigley and Jones 1985, Karl and Riebsame 1989). We estimated that the projected increased precipitation rate associated with climate change (Rind et al. 1989) would increase the mean discharge during the spawning/rearing period an average of $1.14 \mathrm{~m}^{3} / \mathrm{s}$ annually from $1990-2060$, which is not unreasonable considering the observed annual increase of $1.08 \mathrm{~m}^{3} / \mathrm{s}$ from 1931-1979 (Bhowmik et al. 1980). Simulations of the projected 2060 flow regime with present land use suggest that the smallmouth bass population would substantially decrease from its present density, possibly to extinction, in downstream reaches of the Kankakee River (Fig. 6a). However, it remains possible that the species may persist in the basin with an altered distribution into upstream or tributary reaches of the river, where increases in flow may be less intense or prolonged during critical periods. Furthermore, the population could respond genetically through selection to persist among long-term changes in the environment.

Given the great effect that land-use patterns can have on flow regime, we believe that the impact of future climate change could be mitigated via watershed restoration in an attempt to stem or reverse the long-term observed trend of increasing river flows. The increasing trend in Kankakee River mean discharge from 1931 to 1979 was attributed to land-use activities that modified characteristics such as storage capacity, infiltration, and runoff (Bhowmik et al. 1980). Consequently, model simulations of climate-altered temperature and flow regimes estimated under historical land use showed longterm persistence of a smallmouth bass population with an increased density over that of the present providing sustainable yield, whereas climate-altered projections based on present land use predicted local extinction of the species. Our finding that land-use change was of greater detriment to smallmouth bass than climate change supports the contention of Vitousek (1994) that human changes in land use and cover represent the most important component of global change now and in the future. Thus, we suggest that if the watershed landscape was returned to historical conditions, the negative effects of increased temperature and flow associated with global warming would be mitigated or not realized by the smallmouth bass population.

Although it may seem an impractical immediate objective to return a $13377-\mathrm{km}^{2}$ river basin to its historical landscape, we believe that incremental measures would yield positive ecological benefits and may serve as a long-term directional goal to mitigate effects of projected climate change. Restoration activities on this 
large river and floodplain have considerable potential and would primarily occur on flood-prone land that is uneconomical for farming or other human uses, and riparian wetland restoration can be completed with minimal construction (National Research Council 1992, Mitsch and Gosselink 1993, Gore and Shields 1995). In channelized areas of the Kankakee River, oxbows and remnants of the historical river channel remain on the floodplain and may be restored to a more natural flow pattern (Kwak 1993). Watershed and wetland restoration in the Kankakee River basin would provide mutual benefits to channel-dwelling fishes and floodplain productivity, as well as restoring ecological functions that may mitigate other problems associated with water quality, wetland and terrestrial wildlife, and property damage due to flooding. While our empiricalbased simulations have suggested past and future trends in smallmouth bass population response to flow and temperature, we look forward to gaining future insight and model verification and refinement that may be achieved through empirical evaluation of trends over time and adaptive ecosystem management.

\section{ACKNOWLEDGMENTS}

We thank the many individuals who assisted us during the 13-year field portion of this research. We are especially grateful to R. W. Larimore for oversight and administration of field studies and to previous project coordinators T. M. Skelly and the late M. J. Sule. We also thank D. C. Lee for his thorough assistance with model parameter computations. The manuscript was improved with suggestions from D. C. Lee, N. L. Poff, B. E. Rieman, K. A. Rose, W. L. Thompson, and an anonymous reviewer. Field data collection was funded by a grant from the Commonwealth Edison Company to the Illinois Natural History Survey. Publication costs were provided by the U.S. Forest Service, Rocky Mountain Research Station. The Arkansas Cooperative Fish and Wildlife Research Unit is jointly sponsored by the Biological Resources Division of the U.S. Geological Survey, the University of Arkansas, the Arkansas Game and Fish Commission, and the Wildlife Management Institute.

\section{Literature Cited}

Austen, D. J. 1992. Analysis of fish communities in Illinois lakes. Dissertation. Iowa State University, Ames, Iowa, USA.

Bain, M. B., and J. M. Boltz. 1989. Regulated streamflow and warmwater stream fish: a general hypothesis and research agenda. Biological Report 89(18). U.S. Fish and Wildlife Service, Washington, D.C., USA.

Barker, B., J. B. Carlisle, and R. Nyberg. 1967. Kankakee River basin study, a comprehensive plan for water resource development. Illinois Department of Public Works and Buildings, Bureau of Water Resources, Springfield, Illinois, USA.

Bayley, P. B. 1995. Understanding large river-floodplain ecosystems. BioScience 45:153-158.

Bayley, P. B., and D. J. Austen. 1987. Manual for the district fisheries analysis system (FAS): a package for fisheries management and research. Part 1: fish population survey data. Aquatic Biology Technical Report 87/11. Illinois Natural History Survey, Champaign, Illinois, USA.

Bayley, P. B., and D. C. Dowling. 1993. The effects of habitat in biasing fish abundance and species richness estimates when using various sampling methods in streams. Polskie Archiwum Hydrobiologii 40:5-14.
Bhowmik, N. G., A. P. Bonini, W. C. Bogner, and R. P. Byrne. 1980. Hydraulics of flow and sediment transport in the Kankakee River in Illinois. Report of Investigation 98. Illinois State Water Survey, Champaign, Illinois, USA.

Bovee, K. D., and R. Milhous. 1978. Hydraulic simulation in instream flow studies: theory and techniques. Instream Flow Information Paper 5. U.S. Fish and Wildlife Service, Fort Collins, Colorado, USA.

Bovee, K. D., T. J. Newcomb, and T. G. Coon. 1994. Relations between habitat variability and population dynamics of bass in the Huron River, Michigan. Biological Report 21. National Biological Survey, Washington, D.C., USA.

Clark, M. E., K. A. Rose, J. A. Chandler, T. J. Richter, D. J. Orth, and W. Van Winkle. 1998. Simulating smallmouth bass reproductive success in reservoirs subject to water level fluctuations. Environmental Biology of Fishes 51: 161-174.

Cleary, R. 1956. Observations on factors affecting smallmouth bass production in Iowa. Journal of Wildlife Management 20:353-359.

Coble, D. W. 1975. Smallmouth bass. Pages 21-33 in R. H. Stroud and H. Clepper, editors. Black bass biology and management. Sport Fishing Institute, Washington, D.C., USA.

DeAngelis, D. L., L. Godbout, and B. J. Shuter. 1991. An individual-based approach to predicting density-dependent dynamics in smallmouth bass populations. Ecological Modelling 57:91-115.

Eaton, J. G., and R. M. Scheller. 1996. Effects of climate warming on fish thermal habitat in streams of the United States. Limnology and Oceanography 41:1109-1115.

Eipper, A. W. 1975. Environmental influences on the mortality of bass embryos and larvae. Pages 295-305 in R. H. Stroud and H. Clepper, editors. Black bass biology and management. Sport Fishing Institute, Washington, D.C., USA.

Emery, A. R. 1975. Stunted bass: a result of competing cisco and limited crayfish stocks. Pages 154-164 in R. H. Stroud and $\mathrm{H}$. Clepper, editors. Black bass biology and management. Sport Fishing Institute, Washington, D.C., USA.

Fausch, K. D., C. L. Hawkes, and M. G. Parsons. 1988. Models that predict standing crop of stream fish from habitat variables: 1950-85. General Technical Report PNWGTR-213. U.S. Forest Service, Pacific Northwest Research Station, Portland, Oregon, USA.

Firth, P., and S. G. Fisher, editors. 1992. Global climate change and freshwater ecosystems. Springer-Verlag, New York, New York, USA.

Forbes, S. A., and R. E. Richardson. 1920. The fishes of Illinois. Second edition. Illinois Natural History Survey Division, Springfield, Illinois, USA.

Fournier, D., and C. P. Archibald. 1982. A general theory for analyzing catch at age data. Canadian Journal of Fisheries and Aquatic Sciences 39:1195-1207.

Gates, D. M. 1993. Climate change and its biological consequences. Sinauer, Sunderland, Massachusetts, USA.

Giorgi, F., C. Shields Brodeur, and G. T. Bates. 1994. Regional climate change scenarios over the United States produced with a nested regional climate model. Journal of Climate 7:375-399.

Gordon, N. D., T. A. McMahon, and B. L. Finlayson. 1992. Stream hydrology: an introduction for ecologists. John Wiley and Sons, New York, New York, USA.

Gore, J. A., and F. D. Shields, Jr. 1995. Can large rivers be restored? BioScience 45:142-152.

Graham, R. J., R. W. Larimore, and W. F. Dimond. 1984. Recreational fishing in the Kankakee River, Illinois. Biological Notes 120 . Illinois Natural History Survey, Champaign, Illinois, USA.

Grossman, G. D., J. F. Dowd, and M. Crawford. 1990. As- 
semblage stability in stream fishes: a review. Environmental Management 14:661-671.

Grover, N. C., and A. W. Harrington. 1966. Stream flow measurements, records and their uses. Dover, New York, New York, USA.

Guyette, R. P., and C. F. Rabeni. 1995. Climate response among growth increments of fish and trees. Oecologia 104: 272-279.

Harvey, B. C. 1991. Interaction of abiotic and biotic factors influences larval fish survival in an Oklahoma stream. Canadian Journal of Fisheries and Aquatic Sciences 48: 14761480.

Healy, R. W. 1979. River mileages and drainage areas for Illinois streams: Volume 2, Illinois River basin. Water Resources Investigations 79-11. U.S. Geological Survey, Water Resources Division, Champaign, Illinois, USA.

Horning, W. B., II, and R. E. Pearson. 1973. Growth temperature requirements and lower lethal temperatures for juvenile smallmouth bass (Micropterus dolomieui). Journal of the Fisheries Research Board of Canada 30:1226-1230.

Houghton, J. T., G. J. Jenkins, and J. J. Ephraums, editors 1990. Climate change: the IPCC scientific assessment Cambridge University Press, Cambridge, UK.

Houghton, J. T., L. G. Meira Filho, B. A. Callander, N. Harris, A. Kattenberg, and K. Maskell, editors. 1996. Climate change 1995: the science of climate change. Cambridge University Press, Cambridge, UK.

Ivens, J. L., N. G. Bhowmik, A. R. Brigham, and D. L. Gross. 1981. The Kankakee River yesterday and today. Miscellaneous Publication 60. Illinois State Water Survey, Champaign, Illinois, USA.

Jearld, A., Jr. 1983. Age determination. Pages 301-324 in L. A. Nielson and D. L. Johnson, editors. Fisheries techniques. American Fisheries Society, Bethesda, Maryland, USA.

Johnson, B. L., W. B. Richardson, and T. J. Naimo. 1995 Past, present, and future concepts in large river ecology. BioScience 45:134-141.

Junk, W. L., P. B. Bayley, and R. E. Sparks. 1989. The flood pulse concept in river-floodplain systems. Pages 110-127 in D. P. Dodge, editor. Proceedings of the International Large River Symposium. Canadian Special Publication of Fisheries and Aquatic Sciences 106. Department of Fisheries and Oceans, Ottawa, Ontario, Canada.

Kareiva, P. M., J. G. Kingsolver, and R. B. Huey, editors. 1993. Biotic interactions and global change. Sinauer, Sunderland, Massachusetts, USA.

Karl, T. R., and W. E. Riebsame. 1989. The impact of decadal fluctuations in mean precipitation and temperature on runoff: a sensitivity study over the United States. Climatic Change 15:423-447.

Keleher, C. J., and F. J. Rahel. 1996. Thermal limits to salmonid distributions in the Rocky Mountain region and potential habitat loss due to global warming: a geographic information system (GIS) approach. Transactions of the American Fisheries Society 125:1-13.

Kwak, T. J. 1988. Lateral movement and use of floodplain habitat by fishes of the Kankakee River, Illinois. American Midland Naturalist 120:241-249.

1991. Ecological characteristics of a northern population of the pallid shiner. Transactions of the American Fisheries Society 120:106-115.

- 1993. The Kankakee River: a case study and management recommendations for a stream diverse in habitat, fauna, and human values. Pages 123-141 in L. W. Hesse, C. B. Stalnaker, N. G. Benson, and J. R. Zuboy, editors. Proceedings of the symposium on restoration planning for the rivers of the Mississippi River ecosystem. Biological Report 19. National Biological Survey, Washington, D.C., USA.
Kwak, T. J., and R. W. Larimore. 1987. An analysis of environmental and biotic factors affecting catch per unit effort of Kankakee River fishes. Aquatic Biology Section Technical Report 87/09. Illinois Natural History Survey, Champaign, Illinois, USA.

Larimore, R. W. 1975. Visual and tactile orientation in smallmouth bass fry under floodwater conditions. Pages 323332 in R. H. Stroud and H. Clepper, editors. Black bass biology and management. Sport Fishing Institute, Washington, D.C., USA.

Larimore, R. W., and M. J. Duever. 1968. Effects of temperature acclimation on the swimming ability of smallmouth bass fry. Transactions of the American Fisheries Society 97:175-184.

Lenat, D. R., and J. K. Crawford. 1994. Effects of land use on water quality and aquatic biota of three North Carolina Piedmont streams. Hydrobiologia 294: 185-199.

Leopold, L. B., M. G. Wolman, and J. P. Miller. 1964. Fluvial processes in geomorphogy. W. H. Freeman, San Francisco, California, USA.

Leslie, P. H. 1945. On the use of matrices in certain population mathematics. Biometrika 33:183-212.

Lomnicki, A. 1992. Population ecology from the individual perspective. Pages 3-17 in D. L. DeAngelis and L. J. Gross, editors. Individual-based models and approaches in ecology: populations, communities, and ecosystems. Chapman and Hall, New York, New York, USA.

Lukas, J. A., and D. J. Orth. 1995. Factors affecting nesting success of smallmouth bass in a regulated Virginia stream. Transactions of the American Fisheries Society 124:726735.

Matthews, W, J. 1987. Physiochemical tolerance and selectivity of stream fishes as related to their geographic ranges and local distributions. Pages 111-120 in W. J. Matthews and D. C. Heins, editors. Community and evolutionary ecology of North American stream fishes. University of Oklahoma Press, Norman, Oklahoma, USA.

Meisner, J. D. 1990. Potential loss of thermal habitat for brook trout, due to climatic warming, in two southern Ontario streams. Transactions of the American Fisheries Society 119:282-291.

Meyer, A. H. 1936. The Kankakee "marsh" of northern Indiana and Illinois. Papers of the Michigan Academy of Science Arts and Letters 21:359-396.

Mitsch, W. J., and J. G. Gosselink. 1993. Wetlands. Second edition. Van Nostrand Reinhold, New York, New York, USA.

Morhardt, J. E. 1986. Instream flow methodologies. EPRI EA-4819. Electric Power Research Institute, Palo Alto, California, USA.

Morisawa, M. E. 1985. Rivers: form and process. Geomorphology Texts 7, Longman, London, UK.

National Research Council. 1992. Restoration of aquatic ecosystems: science, technology, and public policy. National Academy Press, Washington, D.C., USA.

Neter, J., W. Wasserman, and M. H. Kutner. 1990. Applied linear statistical models. R. D. Irwin, Homewood, Illinois, USA.

Peterson, J. T. 1991. Kankakee River fishes of the Braidwood Station Aquatic Monitoring Area, August 1990. Center for Aquatic Ecology Technical Report 91/1. Illinois Natural History Survey, Champaign, Illinois, USA.

Pflieger, W. L. 1966. Reproduction of smallmouth bass ( $\mathrm{Mi}$ cropterus dolomieui) in a small Ozark stream. American Midland Naturalist 76:410-418.

Poff, N. L. 1992. Regional hydrologic response to climate change: an ecological perspective. Pages 88-115 in P. Firth and S. G. Fisher, editors. Global climate change and freshwater ecosystems. Springer-Verlag, New York, New York, USA. 
Rabeni, C. F. 1992. Trophic linkage between stream centrarchids and their crayfish prey. Canadian Journal of Fisheries and Aquatic Sciences 49:1714-1721.

Rahel, F. J., C. J. Keleher, and J. J. Anderson. 1996. Potential habitat loss and population fragmentation for cold water fish in the North Platte River drainage of the Rocky Mountains: response to climate warming. Limnology and Oceanography 41:1116-1123.

Ricker, W. E. 1954. Stock and recruitment. Journal of the Fisheries Research Board of Canada 11:559-621.

Rind, D., R. Goldberg, and R. Ruedy. 1989. Change in climate variability in the 21 st century. Climatic Change 14: 5-37.

Rind, D., C. Rosenzweig, and R. Goldberg. 1992. Modelling the hydrological cycle in assessments of climate change. Nature 358: 119-122.

Ringold, P. L., and P. M. Groffman. 1997. Inferential studies of climate change. Ecological Applications 7:751-752.

Roell, M. J., and D. J. Orth. 1993. Trophic basis of production of stream-dwelling smallmouth bass, rock bass, and flathead catfish in relation to invertebrate bait harvest. Transactions of the American Fisheries Society 122:46-62.

Ross, S. T., and J. A. Baker. 1983. The response of fishes to periodic spring floods in a southeastern stream. American Midland Naturalist 109:1-14.

Roth, N. E., J. D. Allan, and D. L. Erickson. 1996. Landscape influences on stream biotic integrity assessed at multiple spatial scales. Landscape Ecology 11:141-156.

Sallee, R. D., J. Langbein, H. Brown, and J. Ferencak. 1991. Effects of discharge fluctuations on survival of smallmouth bass in the Kankakee River, Illinois. Pages $90-95$ in D. C. Jackson, editor. The First International Smallmouth Bass Symposium. Mississippi Agricultural and Forestry Experiment Station, Mississippi State University, Mississippi State, Mississippi, USA.

Schlosser, I. J. 1991. Stream fish ecology: a landscape perspective. BioScience 41:704-712.

Shuter, B. J., P. E. Ihssen, D. L. Wales, and E. J. Snucins. 1989. The effects of temperature, $\mathrm{pH}$, and water hardness on winter starvation of young-of-the-year smallmouth bass, Micropterus dolomieui Lacapede. Journal of Fish Biology 35:765-780.

Shuter, B. J., J. A. MacLean, F. E. J. Fry, and H. A. Regier. 1980. Stochastic simulation of temperature effects on firstyear survival of smallmouth bass. Transactions of the American Fisheries Society 109:1-34.

Shuter, B. J., and J. R. Post. 1990. Climate, population viability, and the zoogeography of temperate fishes. Transactions of the American Fisheries Society 119:314-336.

Simonson, T. D., and W. A. Swenson. 1990. Critical stream velocities for young-of-year smallmouth bass in relation to habitat use. Transactions of the American Fisheries Society 119:902-909.

Smith, P. W. 1979. The fishes of Illinois. University of Illinois Press, Urbana, Illinois, USA.

Smith, S. H. 1954. Method of producing plastic impressions of fish scales without using heat. Progressive Fish-Culturist 16:75-78.

Stalnaker, C. B. 1981. Low flow as a limiting factor in warmwater streams. Pages 192-199 in L. A. Krumholz, editor. The Warmwater Streams Symposium. American Fisheries Society, Bethesda, Maryland, USA.

Stocker, M., V. Haist, and D. Fournier. 1985. Environmental variation and recruitment of Pacific herring (Clupea harengus pallasi) in the Strait of Georgia. Canadian Journal of Fisheries and Aquatic Sciences 42 (Supplement 1):174180.

USGS (U.S. Geological Survey). 1997. Historical streamflow daily values for Kankakee River near Wilmington, Illinois. [online: /http://h2o-nwisw.er.usgs.gov/nwis-w/IL/ data.components/hist.cgi? statnum $=05527500\rangle$ ].

Vitousek, P. M. 1994. Beyond global warming: ecology and global change. Ecology 75:1861-1876.

Ward, J. V., and J. A. Stanford. 1989. Riverine ecosystems: the influence of man on catchment dynamics and fish ecology. Pages 56-64 in D. P. Dodge, editor. Proceedings of the International Large River Symposium. Canadian Special Publication of Fisheries and Aquatic Sciences 106. Department of Fisheries and Oceans, Ottawa, Ontario, Canada.

Waters, T. F., J. P. Kaehler, T. J. Polomis, and T. J. Kwak. 1993. Production dynamics of smallmouth bass in a small Minnesota stream. Transactions of the American Fisheries Society 122:588-598

Welcomme, R. L. 1985. River fisheries. Fisheries Technical Paper 262. United Nations Food and Agriculture Organization, Rome, Italy.

Wigley, T. M. L., and P. D. Jones. 1985. Influences of precipitation changes and direct $\mathrm{CO}_{2}$ effects on streamflow. Nature 314:149-152.

Wiley, M. J., S. L. Kohler, and P. W. Seelbach. 1997. Reconciling landscape and local views of aquatic communities: lessons from Michigan trout streams. Freshwater Biology 37:133-148.

Wilkinson, L., M. Hill, and E. Vang. 1992. SYSTAT: statistics. Version 5.2 edition. SYSTAT, Evanston, Illinois, USA.

Winemiller, K. O., and D. H. Taylor. 1982. Smallmouth bass nesting behavior and nest site selection in a small Ohio stream. Ohio Journal of Science 82:266-273.

Wismer, D. A., and A. E. Christie. 1987. Temperature relationships of Great Lakes fishes: a data compilation. Special Publication 87-3. Great Lakes Fishery Commission, Ann Arbor, Michigan, USA. 